\title{
New species of Scolelepis (Polychaeta, Spionidae) from the Norwegian coast and Barents Sea with a brief review of the genus
}

\author{
Andrey V. Sikorskil and Ljudmila V. Pavlova ${ }^{2}$
}

Sikorski AV and Pavlova LV. 2015. New species of Scolelepis (Polychaeta, Spionidae) from the Norwegian coast and Barents Sea with a brief review of the genus. Fauna norvegica 35: 9-19.

The species Scolelepis finmarchicus sp. nov. is described from the Norwegian and Barents Seas along the northern Norwegian coast and Kola peninsula. The occurrence of this species in the Kola Bay could be seen as a sign of climate warming in the area. Taxonomic issues existing in the genus Scolelepis within the area along the Norwegian coast and in the Barents Sea are briefly touched upon. Seven species belonging to Scolelepis have recently been recorded from the Atlantic sector of the Arctic. Scolelepis (S.) matsugae Sikorski, 1994 is newly synonymized with S. (S.) laonicola (Tzetlin, 1985). This article provides a brief review of Scolelepis together with an identification key for the genus from the Atlantic sector of the Arctic.

doi: 10.5324/fn.v35i0.1666. Received: 2014-04-14. Accepted: 2015-04-25. Published online: 2015-10-07. ISSN: 1502-4873 (printed), 1891-5396 (electronic).

http://zoobank.org/59B9DC76-56BC-4046-98B5-951953C34437

Keywords: Polychaeta, Spionidae, Scolelepis, taxonomic review, sexual dimorphism, Norwegian coast, Barents Sea

1. Akvaplan-niva AS, Fram Centre, 9296 Tromsø, Norway

2 Russian Academy of Sciences, Kola Science Centre, Murmansk Marine Biological Institute, Vladimirskaya str. 17, Murmansk 183010, Russia

Corresponding author: Andrey V. Sikorski

http://www.zoobank.org/Authors/F82EA89B-E556-4DEF-855D-C907AB045FC5

E-mail: as@akvaplan.niva.no

\section{INTRODUCTION}

Polychaetes belonging to the genus Scolelepis commonly inhabit sublittoral coastal sandy or mixed soft-bottom substrata. This genus does not appear to extend to the continental slope or abyssal depths (Maciolek 1987: 17).

Currently the genus Scolelepis contains 86 species, 74 species in the subgenus Scolelepis (including the new one) and 12 species in the subgenus Parascolelepis (Table 1). The latest articles (e.g., Delgado-Blas 2006, Blake 2006, Delgado-Blas et al. 2009, dos Santos et al. 2009, Rocha \& de Paiva 2012) have recognized only about 45 species of Scolelepis and 12 of Parascolelepis worldwide, while Rocha et al. (2009) reconized a total of about 80 species. Some authors have used Scolelepis and Parascolelepis as genera rather than subgenera (Blake 2006, Williams 2007). Williams (2007) gave a total of 58-59 species for the genus Scolelepis sensu stricto.

The Scandinavian Arctic spionid fauna has been extensively investigated but new species are still found along the Norwegian coast. The new species described in the paper was obtained from material collected during monitoring activities in 20032009 along the coast of Norway and the Kola Peninsula in northwest Russia.

Brief comments are given in this paper about some recent changes to faunistic and taxonomic details that concern Scolelepis from the Atlantic sector of the Arctic (Sikorski 2001; Vortsepneva et al. 2008). An identification key for all the known Arctic species of Scolelepis is given with short taxonomic notes. 


\section{MATERIAL AND METHODS}

The new species was found in 16 samples. Twenty-two specimens (three specimens were lost) were collected with Van Veen grab and by scuba diving from depths down to 150 $m$ at different locations along the northern coast of Norway by the consulting firm Akvaplan-niva AS (Tromsø, Norway) and from the Kola Bay by the Murmansk Marine Biological Institute (Murmansk, Russia). The material was fixed in 4\% formalin and then transferred to $75 \%$ ethanol. Examination of the material, including the drawings, was done using binocular microscopes (Leica M80 and MZ 12) and transmitted light microscopes (Leica DM2000 and MICMED-6). The type material was deposited in the University Museum of Bergen, University of Bergen, Norway (ZMBN) and in the Zoological Institute of Russian Academy of Sciences, St. Petersburg, Russia (ZISP). All Arctic material from Russian museums (ZISP and the Zoological Museum of the Moscow University (ZMUM) labelled as Scolelepis was examined. In addition two tubes from the Natural History Museum, University of Oslo (NHMO), identified and labeled by M. Sars as "Spio foliosus" from Grøtø (NHMO C5970) and "Spio foliosa" from Øksfjord (NHMO C5971) were examined. The tube labeled by D.C. Danielssen as Nerine foliosa from the University Museum of Bergen (ZMBN 2156, from Grøtøy) and eight specimens from the Zoological Museum of Hamburg labelled Scolelepis squamatus (Müller, 1806) (ZMH P-16127) were examined. One specimen from ZMBN 2156 and one from ZMH P-16127 are now deposited (after obtaining required permissions from the Bergen and Hamburg museums) in the Zoological Museum of the Moscow University (ZMUM Pl 1815 and 1811 respectively). Two cotypes of Nerinides tridentatus Southern, 1914 from the Irish Zoological Museum (Blacksod Bay 42.1910 St. W135 shore March 1910 and Blacksod Bay 448.1910 St. W160 Sept. 1910 - there was no an accession number on the label) were also examined as this name is often used in the species lists produced for the benthic fauna of the Norwegian coast. Material identified as Nerinides tridentatus and deposited in the Zoological Museum of the University of Uppsala (UUZM, Sweden) was also looked at and considered. For $S$. bonnieri Mesnil, 1896 taxonomic literature was examined together with numerous specimens collected by Akvaplan-niva AS from the North and Norwegian Seas since 1992 but not deposited in any proper museum collections.

\section{RESULTS}

\section{Scolelepis Blainville, 1828}

Type species: Lumbricus squamatus Müller, 1806

Diagnosis: Prostomium pointed on anterior margin, sometimes trilobed or rounded, extending posteriorly as narrow caruncle.
Occipital tentacle present or absent. Caruncle posteriorly detached or attached to dorsal body wall. Peristomium well developed, with or without lateral wings. Branchiae beginning on chaetiger 2, continuing to near the posterior end of body; in anterior chaetigers, branchiae completely fused to dorsal lamellae or with distal portion free. Capillary noto- and neurochaetae of anterior chaetigers usually arranged in two tiers; notopodial capillaries of the posterior chaetigers in a single tier. Neuropodial hooded hooks present. Notopodial hooded hooks present or absent. Hooks uni-, bi-, tri- or multidentate. Pygidium with oval disc or multi-lobed appendages.

Remarks: The genus Scolelepis was divided by Maciolek (1987) into two subgenera, Scolelepis and Parascolelepis. This division was based on the structure of the hooks.

\section{Scolelepis (S.) finmarchicus sp. nov.}

(LSID: http://www.zoobank.org/7F1870B0-EB63-449B-8A52720C5D8EF7AA)

Figures 1 (A-I), 2

Scolelepis sp. A - Sikorski, 2001: p.284.

\section{Material examined}

Type-material: 19 specimens. Holotype. Melkøya, Finnmark, Norway, st. 5, grab 3, 70 41' $03^{\prime \prime} \mathrm{N}, 23^{\circ} 33^{\prime} 03^{\prime \prime} \mathrm{E}, 130 \mathrm{~m}, 01$ August 2006 (ZMBN 95132). Paratypes: Norway: Melkøya, st. 2, grab 1, 70 $41^{\prime} 08^{\prime \prime} \mathrm{N}, 23^{\circ} 37^{\prime} 19^{\prime \prime} \mathrm{E}, 62 \mathrm{~m}, 18$ July 2006

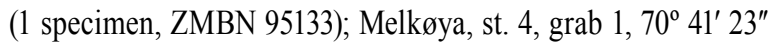
N, $23^{\circ} 34^{\prime} 31^{\prime \prime}$ E, 64 m, 01 August 2006 (1, ZMBN 95134); Melkøya, st. 5, grab 2, 70 $42^{\prime} 03^{\prime \prime} \mathrm{N}, 23^{\circ} 33^{\prime} 03^{\prime \prime} \mathrm{E}, 130 \mathrm{~m}$, 01 August 2006 (1, ZMBN 95135); Melkøya, st. 4, 70 41' 24" N, 23 34' 19" E, 52 m, 06 August 2008 (1, ZMBN 95136);

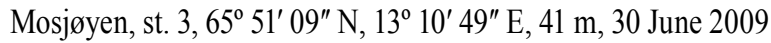
(4, ZMBN 95137); Melkøya, st. 4, grab 2, $70^{\circ} 41^{\prime} 24^{\prime \prime} \mathrm{N}, 23^{\circ} 34^{\prime}$ 19" E, 52 m, 23 August 2010 (1, ZMBN 95138); Melkøya, st. 6, grab $1,70^{\circ} 38^{\prime} 51^{\prime \prime} \mathrm{N}, 23^{\circ} 37^{\prime} 21^{\prime \prime} \mathrm{E}, 60 \mathrm{~m}, 23$ August 2010 (1, ZMBN 95139); Finnmark, st. 658, grab 3, 70 55' 31' N, $25^{\circ} 36^{\prime}$ 47" E, 150 m, 18 September 2003 (1, ZISP 1/50610); Kola Bay, scuba sample, st.11-1, $69^{\circ} 04^{\prime} 46^{\prime \prime} \mathrm{N}, 33^{\circ} 11^{\prime} 56^{\prime \prime} \mathrm{E}, 11 \mathrm{~m}$, silty sand, $8^{\circ} \mathrm{C}$, salinity 34, 26 September 2006 (1, ZMBN 95140); Storvika st. 3B, $67^{\circ} 32^{\prime} \mathrm{N}, 15^{\circ} 18^{\prime} \mathrm{E}, 19 \mathrm{~m}, 21$ May 2014 (1, ZMBN 98030); Melkøya Kystovervåking, st. 4, grab 4, 70 $41^{\prime}$ $23^{\prime \prime} \mathrm{N}, 23^{\circ} 34^{\prime} 31^{\prime \prime} \mathrm{E}, 64 \mathrm{~m}, 11$ August 2014 (1, ZMBN 99283). Russia: Kola Bay, Mishukovo, $69^{\circ} 03^{\prime} \mathrm{N}, 33^{\circ} 04^{\prime} \mathrm{E}$, scuba samples, st.14-2 and 3, $8 \mathrm{~m}, 7^{\circ} \mathrm{C}$, salinity 34,5 , silty sand, 18 September 2006 (2, ZMBN 95141 and 95148); Kola Bay, 69 $07^{\prime}$ $\mathrm{N}, 33^{\circ} 23^{\prime} 35^{\prime \prime} \mathrm{E}$, scuba sample $13-3,6 \mathrm{~m}, 6,9^{\circ} \mathrm{C}$, salinity 33,5 , silty sand with broken shells and pebbles, 21 October 2009 (1, ZMBN 95142; 1, ZISP 2/50611).

Non type-material: 2 specimens from Vågsøy $62^{\circ} 01^{\prime} \mathrm{N}, 05^{\circ} 08^{\prime}$ $30^{\prime \prime} \mathrm{E}, 13$ and 18,5 m, silty broken shells with gravel (deposited in ZMUM, but recently lost); Melkøya, st. 5, grab 3, 70 42' $03^{\prime \prime}$ $\mathrm{N}, 23^{\circ} 33^{\prime} 03^{\prime \prime} \mathrm{E}, 130 \mathrm{~m}, 01$ August 2006 (1 specimen lost during drawing preparation). 


\begin{tabular}{|c|c|c|}
\hline & Species & Type locality \\
\hline 1. & S. (S.) squamata (Müller, 1806) & Denmark \\
\hline 2. & S. (S.) longirostris (Quatrefages, 1843) & English Chanel (Saint-Malo) \\
\hline 3. & S. (P.) foliosus (Auduoin and Milne Edwards, 1833) & France \\
\hline 4. & S. (S.) agilis (Verrill, 1873) & Vineyard Sound \\
\hline 5. & S. (S.) bonnieri Mesnil, 1896 & English Chanel \\
\hline 6. & S. (S.) perrieri (Fauvel, 1902) & Casamance, Senegal \\
\hline 7. & S. (S.) lefebvrei (Gravier, 1905) & Red Sea \\
\hline 8. & S. (S.) lamellata (McIntosh, 1909) & Atlantic Ocean, Tangiers Bay \\
\hline 9. & S. (S.) alaskensis (Treadwell, 1914) & Pacific Ocean, Shumagin Islands, Alaska \\
\hline 10. & S. (S.) acuta (Treadwell, 1914) & Pacific Ocean, San Diego, California \\
\hline 11. & S. (S.) cantabra (Rioja, 1918) & Cantabrian Sea \\
\hline 12. & S. (S.) antipoda (Augener, 1926) & New Zealand \\
\hline 13. & S. (S.) cirratulus hirsuta (Treadwell, 1928) & $05^{\circ} 32^{\prime} \mathrm{N}, 86^{\circ} 59^{\prime} \mathrm{W}$ \\
\hline 14. & S. (S.) minuta (Treadwell, 1939) & Gulf of Mexico, Texas \\
\hline 15. & S. (S.) squamata saipanensis (Hartman, 1954) & Pacific Ocean, Saipan, Marianas Islands \\
\hline 16. & S. (S.) arenicola (Hartmann-Schröder, 1959) & Pacific Ocean, El Salvador \\
\hline 17. & S. (S.) oligobranchia Khlebovitsch, 1959 & Pacific Ocean, Kurile Islands \\
\hline 18. & S. (S.) pigmentata (Reish, 1959) & Pacific Ocean, southern California \\
\hline 19. & S. (S.) knightjonesi (Silva, 1961) & Ceylon \\
\hline 20. & S. (S.) williamsi (Silva, 1961) & Ceylon \\
\hline 21. & S. (S.) maculata Hartman, 1961 & Pacific Ocean, California \\
\hline 22. & S. (S.) occidentalis Hartman, 1961 & Pacific Ocean, California \\
\hline 23. & S. (S.) chilensis (Hartmann-Schröder, 1962) & Pacific Ocean, Chili \\
\hline 24. & S. (S.) goodbodyi Jones, 1962 & Jamaica \\
\hline 25. & S. (S.) mesnili (Bellan and Lagardère, 1971) & Ile d'Oleron, Charente, France \\
\hline 26. & S. (S.) squamata mendanai Gibbs, 1971 & Pacific Ocean, Solomon Islands \\
\hline 27. & S. (S.) aitutaki Gibbs, 1972 & Pacific Ocean, Cook Islands \\
\hline 28. & S. (S.) unidentata (Day, 1973) & Atlantic, North Carolina, Beaufort \\
\hline 29. & S. (S.) gaucha (Orensanz and Gianuca, 1974) & Brasil, Rio Grande do sul \\
\hline 30. & S. (S.) carunculata Blake and Kudenov, 1978 & Australia, Westernport, Victoria \\
\hline 31. & S. (S.) lamellicinata Blake and Kudenov, 1978 & Australia, Westernport, Victoria \\
\hline 32. & S. (S.) occipitalis Blake and Kudenov, 1978 & Australia, Burwood Beach, New South Wales \\
\hline 33. & S. (S.) phyllobranchia Blake and Kudenov, 1978 & Australia \\
\hline 34. & S. (S.) precirriseta Blake and Kudenov, 1978 & Australia, Brisbane, Queensland \\
\hline 35. & S. (S.) victoriensis Blake and Kudenov, 1978 & Australia, Westernport, Victoria \\
\hline 36. & S. (S.) viridis Blake and Kudenov, 1978 & Australia, Great Barrier Reef, Queensland \\
\hline 37. & S. (S.) balihaiensis Hartmann-Schröder, 1979 & Australia, Western Australia \\
\hline 38. & S. (S.) vexillatus Hutchings and Ranier, 1979 & Australia, Careel Bay, New South Wales \\
\hline 39. & S. (S.) blakei Hartmann-Schröder, 1980 & Australia, Dampier, Western Australia \\
\hline 40. & S. (S.) kudenovi Hartmann-Schröder, 1981 & Australia, Western Australia \\
\hline 41. & S. (S.) bullibranchia Rossi, 1982 & Pacific Ocean, California \\
\hline 42. & S. (S.) eltaninae Blake, 1983 & Antarctic Ocean \\
\hline 43. & S. (S.) denmarkensis Hartmann-Schröder, 1983 & Australia, Western Australia \\
\hline 44. & S. (S.) bifida Hutchings and Turvey, 1984 & Australia, South Australia \\
\hline
\end{tabular}


Table I. Continued.

\begin{tabular}{|c|c|c|}
\hline & Species & Type locality \\
\hline 45. & S. (S.) edmondsi Hutchings and Turvey, 1984 & Australia, South Australia \\
\hline 46. & S. (S.) hutchingsae Dauer, 1985 & Australia, Lizard Island, Great Barrier Reef \\
\hline 47. & S. (P.) laonicola (Tzetlin, 1985) & White Sea, Kandalaksha Bay \\
\hline 48. & S. (S.) pettiboneae Maciolek, 1987 & Atlantic Ocean, Georgia, USA \\
\hline 49. & S. (S.) quadridentata Maciolek, 1987 & Atlantic Ocean, Virginia, USA \\
\hline 50. & S. (S.) westoni Maciolek, 1987 & Atlantic Ocean, North Carolina, USA \\
\hline 51. & S. (S.) anakenae Rozbaczylo \& Castilla, 1988 & Pacific Ocean, Easter Island \\
\hline 52. & S. (S.) magnus Ozolinsh, 1990 & Pacific Ocean, Peter the Great Bay, Sea of Japan \\
\hline 53. & S. (S.) brevibranchia Hartmann-Schröder, 1991 & Pacific Ocean, southerm Chile \\
\hline 54. & S. (S.) crenulata Hartmann-Schröder, 1991 & Pacific Ocean, southern Chile \\
\hline 55. & S. (S.) branchia Imajima, 1992 & Pacific Ocean, Japan \\
\hline 56. & S. (S.) lingulata Imajima, 1992 & Pacific Ocean, Japan \\
\hline 57. & S. (S.) planata Imajima, 1992 & Pacific Ocean, Japan \\
\hline 58. & S. (S.) sagittaria Imajima, 1992 & Pacific Ocean, Japan \\
\hline 59. & S. (S.) variegata Imajima, 1992 & Pacific Ocean, Japan \\
\hline 60. & S. (S.) laciniata Eibye-Jacobsen, 1997 & Thailand, Phuket Island \\
\hline 61. & S. (S.) marionis Branch, 1998 & Marion Island \\
\hline 62. & S. (S.) dicha Hutchings, Frouin \& Hily, 1998 & French Polynesia, Tahiti \\
\hline 63. & S. (S.) melasma Hutchings, Frouin \& Hily, 1998 & French Polynesia, Tahiti \\
\hline 64. & S. (S.) vazaha Eibye-Jacobsen \& Soares, 2000 & South west Indian Ocean, Madagascar, Cap Est \\
\hline 65. & S. (S.) eltaninae nudipalpa Cantone \& Pietro, 2001 & Antarctic Ocean, Antarctica, Ross Sea, Terra Nova Bay \\
\hline 66. & S. (S.) lighti Delgado-Blas, 2006 & Gulf of Mexico, Tamaulipas: La Pesca \\
\hline 67. & S. (S.) vossae Delgado-Blas, 2006 & Florida, Atlantic coast \\
\hline 68. & S. (S.) alisonae Williams, 2007 & Philippines, Morong, Bataan \\
\hline 69. & S. (S.) magnicornuta Williams, 2007 & Philippines, Diniwid Beach, Boracay \\
\hline 70. & S. (S.) villosivaina Williams, 2007 & Philippines, Diniwid Beach, Boracay \\
\hline 71. & S. (S.) daphoinos Zhou, Ji \& Li, 2009 & northern China seas \\
\hline 72. & S. (S.) andradei Delgado-Blas, Diaz \& Linero-Arana, 2009 & Caribbean Sea, Venezuela \\
\hline 73. & S. (S.) angulata Zhou, 2014 & Yellow Sea (3259.469’N, 12053.014’ E) \\
\hline 74. & S. (S.) finmarchicus sp. nov. & Finnmark, Norway \\
\hline 1. & S. (P.) tridentata (Southern, 1914) & Atlantic Ocean, Ireland, Clare Island \\
\hline 2. & S. (P.) papillosa (Okuda, 1937) & Pacific Ocean, Korea \\
\hline 3. & S. (P.) yamaguchii (Imajima, 1959) & Pacific Ocean, Japan \\
\hline 4. & S. (P.) gilchristi (Day, 1961) & South Africa \\
\hline 5. & S. (P.) bousfieldi Pettibone, 1963 & $\begin{array}{l}\text { North Atlantic Ocean, Canada, Prince Edward Island, New } \\
\text { London Bay }\end{array}$ \\
\hline 6. & S. (P.) globosa Wu \& Chen, 1964 & intertidal flat around Zhoushan archipelago, East China Sea \\
\hline 7. & S. (P.) quinquedentata Hartmann-Schröder, 1965 & Pacific Ocean, Chile \\
\hline 8. & S. (P.) texana Foster, 1971 & Gulf of Mexico \\
\hline 9. & S. (P.) towra Blake and Kudenov, 1978 & Australia, Botany Bay, New South Wales \\
\hline 10. & S. (P.) carrascoi (Carrasco, 1981) & Pacific Ocean, Chile \\
\hline 11. & S. (P.) burkovskii Sikorski, 1994 & Barents Sea, Kolguev Isl. $\left(69^{\circ} 08^{\prime} \mathrm{N}, 50^{\circ} 22^{\prime} \mathrm{E} ; 19 \mathrm{~m}\right.$, sand) \\
\hline 12. & S. (P.) korsuni Sikorski, 1994 & northern North Sea $\left(59^{\circ} 57^{\prime} 42^{\prime \prime} \mathrm{N}, 02^{\circ} 23^{\prime} 44^{\prime \prime} \mathrm{E} ; 108 \mathrm{~m}\right)$ \\
\hline
\end{tabular}




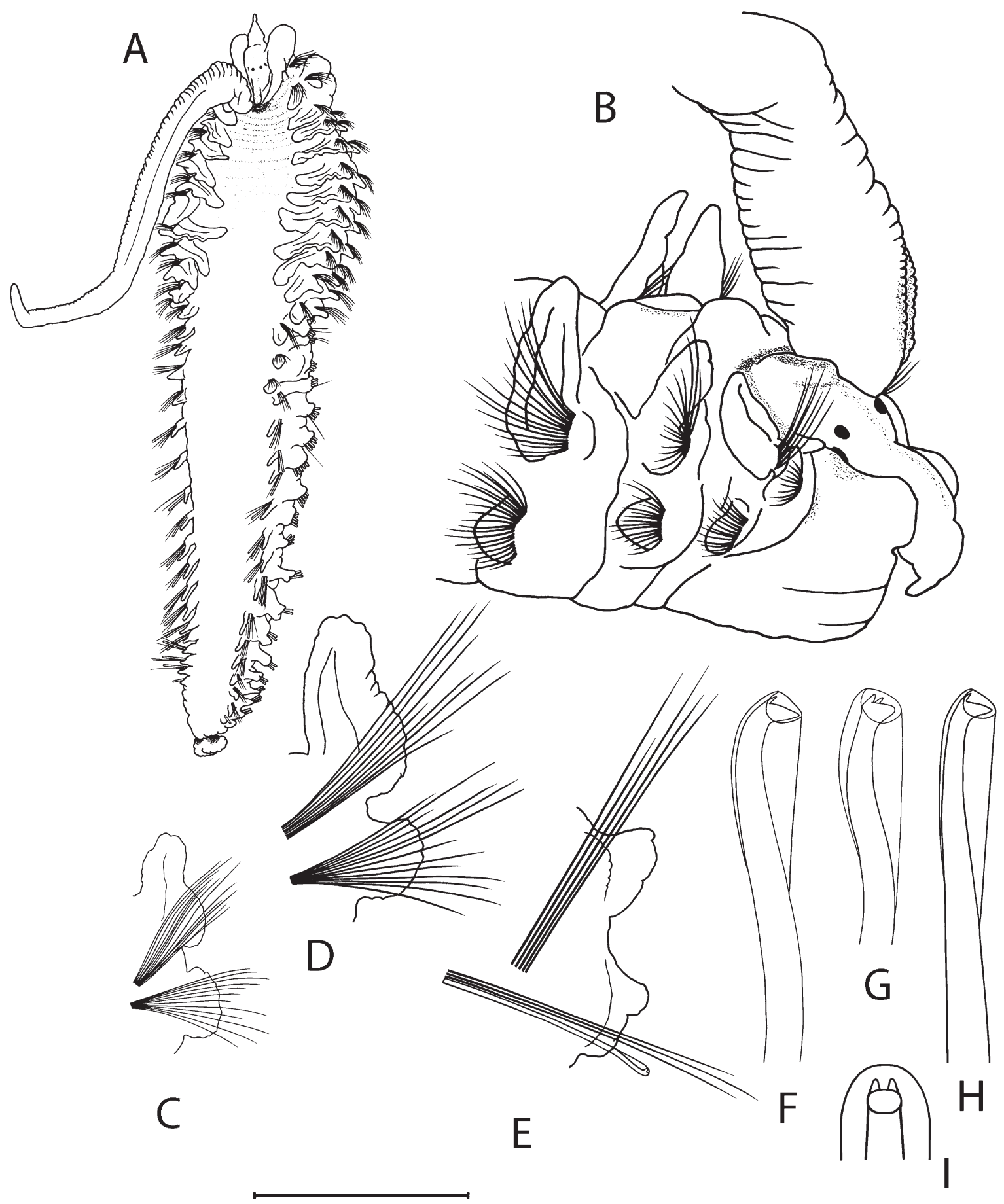

Figure I. Scolelepis finmarchicus n.sp. A. dorsal view of the whole worm; B. anterior part of body, side view; C. parapodium of setiger 5; D. parapodium of chaetiger 12; E. parapodium of chaetiger 15; F. neuropodial hook, side view, chaetiger 17; G. neuropodial hook, three-quarter view, chaetiger 17; H. notopodial hook, side view, chaetiger 17; I. hook full face view, chaetiger 17, scheme. Material: A-B

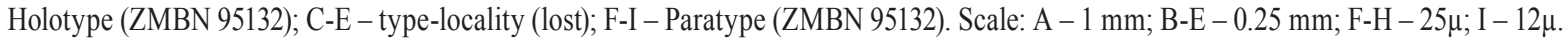




\section{Description}

HOLOTYPE (Figure $1 \mathrm{~A}$ ): Complete specimen $0.7 \mathrm{~mm}$ wide and $3.5 \mathrm{~mm}$ long for 30 chaetigers. Prostomium pointed anteriorly, not narrowing into a pointed caruncle posteriorly but swollen; with two pairs of eye spots arranged in nearly straight transverse line curving slightly backwards, eye spots of lateral pair are crescent-shaped. No occipital papilla. Palps long, reaching chaetiger 17 . Branchiae from chaetiger 2, completely fused to notopodial lamellae, forming comparatively large, broadly rounded notopodial postchaetal lobes on anterior 13 chaetigers, abruptly decreasing posteriorly. Notopodial postchaetal lobes of maximal size on chaetigers $9-10$ becoming slightly notched in the lower parts on chaetigers bearing hooks (Figure 1 E). Neuropodial postchaetal lobes small and rounded along the body. Chaetiger 1 lacks notochaetae. Neuropodial hooded hooks from chaetiger 12, up to 4 per fascicle; notopodial hooded hooks from chaetiger 15, 1 per fascicle. Hooded hooks bifid in side view with paired apical teeth (Figures 1 F-I). Pygidium with a rounded bilobed cushion (Figure 1 A). With obvious dark pigmentation posteriorly on prostomium (caruncle), on and around base of palps, base of pygidial cushion with darkest pigmentation.

\section{Description of all type material (holotype and paratypes)}

Two paratypes intact (ZMBN 98030 and 99283), $0.5 \mathrm{~mm}$ wide and $3.2 \mathrm{~mm}$ long with 26 chaetigers. Width of all specimens

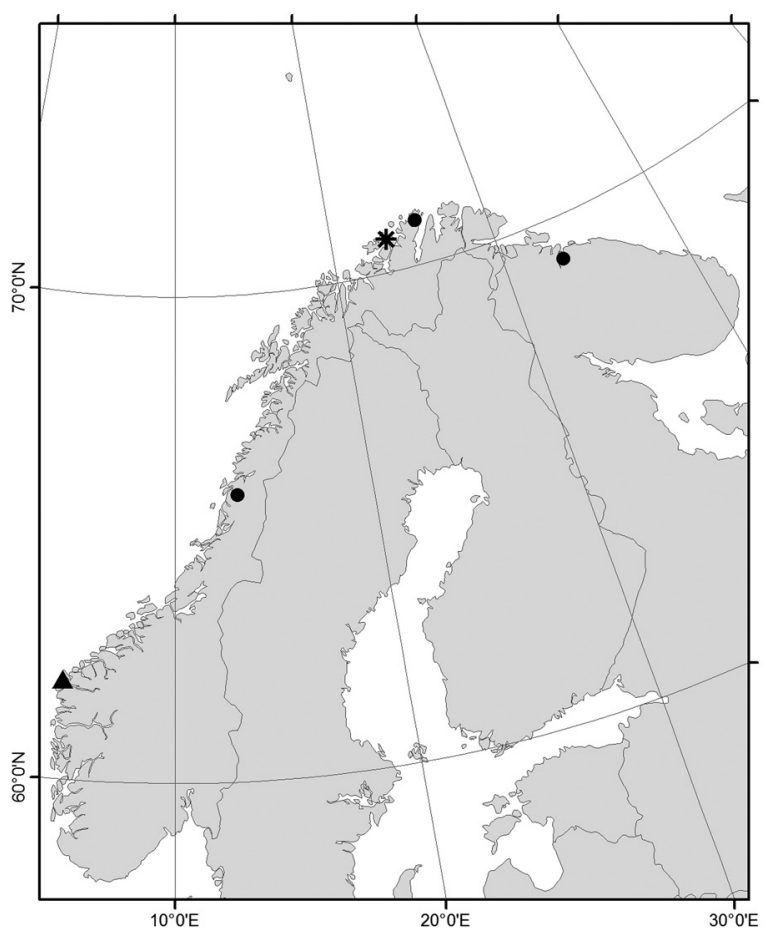

Figure 2. Scolelepis finmarchicus n.sp. Distribution of the material belonging to Scolelepis finmarchicus n.sp. Asterisk - type-locality; filled circles - paratypes; triangle - non type material (lost).
0.4-1.1 mm, length less than $4 \mathrm{~mm}$ for fewer than 30 chaetigers. Prostomium pointed anteriorly, tip of prostomium of fixed specimens directed ventrally (Figure $1 \mathrm{~B}$ ), posterior part swollen with two pairs of eye spots arranged in nearly straight transverse line curving slightly backwards, lateral pair crescentshaped. No occipital papilla (Figure $1 \mathrm{~B}$ ). Palps are of various lengths reaching to between chaetigers 7 and 17 (Figure 1 A). No sheath at the base of the palp (Figure 1 B). Branchiae from chaetiger 2, completely fused to notopodial lamellae forming comparatively large broadly rounded notopodial postchaetal lobes on anterior 12-15 chaetigers (Figure 1 C-D), decreasing abruptly posteriorly. Maximum size of notopodial postchaetal lobes from chaetigers 9 to $10-12$, becoming slightly notched in its lower parts on chaetigers bearing hooks (Figure $1 \mathrm{E}$ ). Chaetiger 1 lacks notochaetae; one paratype (ZMBN 95148) with single capillary present. Neuropodial hooded hooks appear from chaetiger 11-14, 3-5 per fascicle; notopodial hooded hooks appear from chaetiger 13-17, numbering 1-2 per fascicle. The distance between appearance of neuropodial and notopodial hooded hooks is 2-5 segments; this character is size-related (the maximum value was observed in the largest specimen: ZMBN 95139). Hooded hooks bifid in side view (Figure $1 \mathrm{~F}, \mathrm{H}$ ): main fang surmounted by a pair of apical teeth placed side by side (Figure $1 \mathrm{G}, \mathrm{I}$ ). Pygidium with a rounded bilobed ventral cushion (Figure $1 \mathrm{~A}$ ).

\section{Color}

Obvious dark pigmentation on posterior prostomium (caruncle), on base of palps, around base of palps; darkest pigmentation around base of pygidial cushion. Diffuse dark pigmentation present on dorsal side of anterior 5-10 chaetigers in many specimens. Specimens from the Kola Bay have the most intense pigmentation.

\section{Differential diagnosis and remarks}

The material belonging to $S$. (S.) finmarchicus sp. nov. resembles the type-specimens of Nerinides tridentatus (as they were labeled by Southern in 1914) as the branchiae are completely fused to notopodial postchaetal lobes along the body. Typespecimens of $N$. tridentatus are however bigger (more than 60 chaetigers), without hooks in notopodia, with a high prostomial occipital crest and with a prostomium which anteriorly does not become gradually acute but instead has a very small and narrow peak on the anterior margin. We do not know of any other species with such a complex of characters: completely fused (without a notch) branchia and notopodial postchaetal lobes, a prostomium narrowing to acute anteriorly, the absence of an occipital tentacle and the presence of notopodial hooded hooks. S. finmarchicus sp. nov. exhibits the traits inherent to subgenus Scolelepis, e.g. shape of hooded hooks, the presence of slightly notched neuropodial lamella, notopodial hooks, and the absence of a papillated sheath at the base of palps. 


\section{Etymology}

The species is named after a county in the extreme northeastern part of Norway: Finnmark (the county was formerly known as Finmarkens $a m t)$, the region of its type locality.

\section{Biology and ecology}

No eggs or sperm were detected in the specimens examined. Found from 3 to $150 \mathrm{~m}$ depth on mixed bottoms.

\section{Distribution}

Along the Norwegian coast from Vågsøy $\left(62^{\circ} 01^{\prime} \mathrm{N} 05^{\circ} 08^{\prime} 30^{\prime \prime} \mathrm{E}\right)$ north to Finnmark and east to the Kola Bay in the Barents Sea (Figure 2).

\section{DISCUSSION}

Seven species of Scolelepis have been recorded from the Atlantic sector of the Arctic: $S$. (S.) squamatus (O.F. Müller, 1806); S. (S.) foliosus (Audouin \& Milne Edwards, 1833); S. (S.) bonnieri (Mesnil, 1896); S. (S.) laonicola (Tzetlin, 1985); S. (P.) korsuni Sikorski, 1994; S. (P.) burkovskii Sikorski, 1994 and S. (S.) matsugae Sikorski, 1994. The species $S$. (P.) tridentatus (Southern, 1914) does not occur in the area examined (see "Differential diagnosis and remarks"). Former records of this name along the Scandinavian coast were usually associated with specimens belonging to the species $S$. (P.) korsuni - for example Nerinides tridentatus (UUZM 2667: Uppsala Exp.-33, Skagerak, St.4, Eh.2) identified by A. Eliason (1962: 263).

Currently there are 86 valid species-names in the genus Scolelepis (Table 1). Maciolek (1987) provided an important revision of Scolelepis and divided it into two subgenera, Scolelepis and Parascolelepis. This division is based mainly on the morphology of the hooded hooks (Maciolek 1987: 16-17) and has been used by subsequent authors (e.g., Delgado-Blas 2006; Zhou et al. 2009; Rocha \& de Paiva 2012). Some authors have used the two as genera rather than subgenera (Blake 2006, Williams 2007).

The species Asetocalamyzas laonicola was described by Tzetlin (1985) from the White Sea based on a small parasitic worm obtained from a specimen of Laonice cirrata. The original description was based on a single specimen (Holotype - ZMUM PL 307), which exists today as a series of histological sections. In 2008 Tzetlin and Vortsepneva established that it was actually a dwarf male, which usually parasitizes females of the same species. This statement was supported by genetic analysis (Vortsepneva et al. 2008). Before the genetic analysis, females of this species were identified by Vortsepneva as $S$. (S.) matsugae (Vortsepneva et al. 2008) based on examination of the type-specimens of $S$. matsugae deposited in Zoological museum of Moscow University (ZMUM Pl818-820). Based on personal discussions, Tzetlin and Vortsepneva both agree with our opinion that $S$. (S.) matsugae should be treated as a junior synonym of $S$. (S.) laonicola, although they did not state that conclusion in their paper (Vortsepneva et al. 2008). This case of morphologically different males and females in $S$. (S.) laonicola demonstrates an extreme type of sexual dimorphism (Vortsepneva et al. 2008). 23 years after type-description a paratype for A. laonicola (ZMUM PL 976 - female with two males) was erroneously (pers. comm. Elena Vortsepneva) erected in Vortsepneva et al. (2008). Therefore, the type series consists only of the holotype, which represents just the dwarf parasitic male existing as a series of sections. No type specimen exists for the female. In this case attention should be paid to the erection of a neotype for this species.

The species $S$. (S.) finmarchicus sp. nov. is described from the Norwegian and Barents Seas (Norwegian coast north of latitude $62^{\circ} \mathrm{N}$ and Kola peninsula). It should be noted that despite the fauna of the Barents Sea being one of the best studied in the Arctic (Rzhavsky et al. 2011) and there being regular detailed research of the benthos from the Kola Bay area for over a century the new species described in this paper has never been previously recorded. Moreover, one of the authors of this paper (A. Sikorski) worked on the Barents Sea coast of the Kola Peninsula from 1984 until 1989 with a special interest in the spionid fauna of the coastal biotopes. The genus Scolelepis was one of the main objectives of his investigations at that time, but this newly described species was never recorded. The new species was found in several samples from the Kola Bay and it is likely that this species is a recent invasive one and may be indicative of warming in the southern part of the Barents Sea. Similar logic was used by Rzhavsky et al. (2011: 166) to support the statement about "recent invaders". The occurrence of the species Aonides paucibranchiata could also be a good example of this statement: it had never been recorded along the coast of the Kola Peninsula before 2007, but is now common in this area (Anisimova et al. 2009; Rzhavsky et al. 2011; Lyubina et al. 2012b - the material collected in 2007; Deart \& Britayev 2014). In 1987-1988 A. Sikorski was involved as identifier of Polychaeta in a seasonal and very detailed survey of Jarnyshnaja Inlet which was carried out by the Laboratory of Marine Research of the Leningrad Zoological Institute of USSR Academy of Science (Golikov et al. 1989) and A. paucibranchiata was not recorded there. Today, however, it is common in the area (Rzhavsky et al. 2011; Lyubina et al. 2012b; Deart \& Britayev 2014).

The case of $S$. (P.) korsuni Sikorski, 1994 is another good example illustrating the warming of water in the Barents Sea. At the time this species was described in 1992, the author had the only specimen obtained from the Barents Sea. It was collected during a benthic survey in the Barents Sea from the station (R/V “Tunets": st. $105.20,73^{\circ} 01^{\prime} \mathrm{N}, 22^{\circ} \mathrm{OO}$ ) E, 440-450 $\mathrm{m}$, silt, 04.07.1978) on the south-western border of the sea. The entire content of a Sigsbee Trawl was collected. The volume of washed and formalin-fixed sediment was approximately 100 liters. In the following years this sample was offered by Igor Jirkov to students as an exercise at a workshop for sorting at the Department of Hydrobiology, Moscow State University. Only 
one specimen of this species was found in the huge volume of sediment that was processed. The species was described only when the author had the opportunity in 1992 to work with benthic material from the North Sea. Today this species is common in the Barents Sea, occurring almost everywhere: in Ambrose et al. (2009) this species was obtained from the Barents Sea from 26 of the 47 stations sampled (P.E. Renaud, pers. comm.). This species is mentioned as a common one from the Barents Sea by Frolova et al. (2011), Matishov et al. (2011 and 2012), and Lyubina et al. (2012a).

Traits given in the key for $S$. (S.) bonnieri work only for large

Identification key for Scolelepis from the Atlantic sector of the Arctic:

1. Prostomium narrowing to acute anteriorly Prostomium anteriorly trilobed or rounded . .2 .6

2. Branchiae and notopodial postchaetal lobes completely fused on anterior chaetigers 3

- Tips of branchiae and notopodial postchaetal lobes not fused

3. No hooks in middle notopodia; occipital tentacle present S. (P.) korsuni

- Hooks present in middle notopodia; no occipital tentacle S. (S.) finmarchicus sp.n.

4. Tips of branchiae and notopodial postchaetal lobes on anterior chaetigers rounded (not acute) S. (P.) burkovskii

- Tips of branchiae and notopodial postchaetal lobes on anterior chaetigers acute

5. Occipital tentacle large; hooks generally unidentate S.(S.) bonnieri

- Occipital tentacle absent; hooks bidentate S. (S.) squamatus

6. Hooded hooks with 3 apical teeth; fused branchiae and notopodial postchaetal lobes decrease in size abruptly after chaetiger 22-30; hooks appear on chaetiger 11-30. Comparatively small animals: up to 75 chaetigers for $25 \mathrm{~mm}$ long, up to $2.8 \mathrm{~mm}$ wide (incomplete individual) S. (S.) laonicola* * sexual dimorphism is inherent in this species: dwarf male, which usually parasitizes females

- Hooded hooks unidentate or bidentate in smallest individuals; fused branchiae and notopodial postchaetal lobes decrease in size gradually along the body; hooks appear on much more posterior segments. Comparatively larger animals: more than $16 \mathrm{~cm}$ long and up to $11 \mathrm{~mm}$ wide S. (S.) foliosus individuals of more than $0.7 \mathrm{~mm}$ wide as smaller specimens of S. (S.) bonnieri do not have a pronounced occipital tentacle and also unidentate hooks are usually detected only in large specimens. Scolelepis sp. B mentioned in Sikorski (2001: 285) most likely belongs to $S$. (S.) bonnieri. In the case of S. foliosus, (together with $S$. (S.) squamatus and $S$. (S.) bonnieri), the states of different characters (including the shape of hooks, shape of body and several other morphological and numeric characters) should be carefully investigated and described for specimens which are less than $0.7 \mathrm{~mm}$ wide, as we can now confidently operate only with characters from large individuals. Scolelepis (S.) foliosus and $S$. (S.) laonicola are morphologically very close mainly due to the shape of prostomium, the branchiae that are completely fused to notopodial postsetal lobes anteriorly, and the existence of a basal sheath on the palps (Fauvel 1927: 34; Vortsepneva et al. 2008).

With regard to $S$. burkovskii, palps were missing in type specimens but because of the absence of hooded hooks in the notopodia and the absence of notched neuropodia this species may be affiliated with the subgenus Parascolelepis.

\section{ACKNOWLEDGEMENTS}

The authors thank Akvaplan-niva and the Murmansk Marine Biological Institution (MMBI) for providing the opportunity to use material collected for the purpose of ecological monitoring in this work; especially Chris Emblow (Akvaplan-niva) for linguistic assistance, R. Palerud (Akvaplan-niva AS) for assistance in preparing the maps and divers Yu. A. Zuev and S.V. Goldin for the sampling in the Kola Bay. The authors express their sincere thanks to Dr. Brendan O' Connor (AQUAFACT International Services Ltd., Galway, Ireland) for the help in obtaining of the type-specimens of Nerinides tridentatus from the Irish Zoological Museum for examination and to Professor Tor A. Bakke and Ann-Helén Rønning (Natural History Museum, University of Oslo) for providing the opportunity to work with the material identified by M. Sars. To all the people who responded to requests to send material, we express our sincere gratitude.

\section{REFERENCES}

Ambrose JWG, Renaud PE, Cochrane S, Denisenko S, Skarðhamar J. 2009. Polychaete diversity patterns on two Arctic shelves: impacts of ice and primaryproduction? Zoosymposia 2: 457-485.

Anisimova NA, Manushin IE, Lyubin PA. 2009. Benthos. Coast of the East Murman: environmental research areas of the Shtokman project. Murmansk, Publisher PINRO: 85-132 (in Russian).

Audouin JV, Milne Edwards H. 1833. Classification des Annélides et description de celles qui habitent les côtes de la France. Annales des sciences naturelles, Paris, sér. 1(29): 388-412.

Augener H. 1926. Papers from Dr. Th. Mortensen's Pacific 
Expedition 1914-16. XXXIV. Polychaeta III. Polychaeten von Neuseeland. II. Sedentaria. Videnskabelige Meddelelser fra Dansk naturhistorisk Forening i Köbenhavn 81: 157-294.

Bellan G, Lagardère F. 1971. Nerine mesnili, n. sp., spionidien méconnu des plages sableuses de la province Lusitanienne. Bulletin de la Société Zoologique de France 96(4): 571-579.

Blake JA. 1983. Polychaetes of the family Spionidae from South America, Antarctica and adjacent seas and islands. Biology of the Antarctic Seas XIV Antarctic Research Series 39(3): 205288.

Blake JA, Kudenov JD. 1978. The Spionidae (Polychaeta) from southeastern Australia and adjacent areas with a revision of the genera. Memoirs of the National Museum of Victoria 39: 171-280.

Blake JA. 2006. Spionida. In: Rouse G. \& Pleijel F. (eds). Reproductive biology and phylogeny of Annelida. Vol. 4. Reproductive biology and phylogeny. Science Publisher, Enfield, NH: 565-638.

Branch ML. 1998. Four new species of Polychaeta from subantarctic Marion Island. Annals of the South African Museum 105(4): 249-265.

Cantone G, Di Pietro N. 2001. Benthic littoral Polychaeta Sedentaria of Terra Nova Bay (Ross Sea, Antarctica). Antarctic Science 13(1): 3-8. http://dx.doi.org/10.1017/S0954102001000025

Carrasco FD. 1981. Una nueva especie de Scolelepis (Polychaeta, Spionidae) proveniente de Chile. Boletin de la Sociedad de Biologia de Concepción 51: 161-165.

Chlebovitsch VV. 1959. [Species of Polychaeta worms from the Kurile Islands, which are new or recorded for the first time in the USSR fauna]. Zoologicheskii zhurnal 38(1): 167-181 (in Russian).

Dauer DM. 1985. A new species of Scolelepis (Polychaeta: Spionidae) from Lizard Island, Australia. Proceedings of the Biological Society of Washington 98(3): 678-681.

Day JH. 1961. The Polychaete Fauna of South Africa. Part 6. Sedentary species dredged off Cape coasts with a few new records from the shore. Journal of the Linnean Society of London 44(299): 463-560. Published online. http://dx.doi. org/10.1111/j.1096-3642.1961.tb01623.x

Day JH. 1973. New polychaeta from Beaufort, with a key to all species recorded from North Carolina. NOAA Technical Reports, Ser. National Marine Fisheries Service, Circulars 375: 1-140.

Deart YV, Britayev TA. 2014. "New" benthic community with dominance of (POLYCHAETA, OWENIIDAE) at Murman coast: structure and causes of appearance. Doklady Akademii Nauk 454(2): 1-5.

Delgado-Blas VH. 2006. Partial revision of Scolelepis (Polychaeta: Spionidae) from the Grand Caribbean Region, with the description of two new species and a key to species recorded to species recorded in the area. Contributions to Zoology 75(1/2): 75-97.

Delgado-Blas VH, Diaz OFD, Liñero-Arana I. 2009. New record and new species of Scolelepis (Polychaeta: Spionidae) from the Venezuelan, Caribbean. Journal of Marine Biological Association of the United Kingdom 88: 1-5. http://dx.doi. org/10.1590/S1984-46702012000400011

Eibye-Jacobsen D. 1997. A new species of Scolelepis (Polychaeta: Spionidae), highly abundant on the sand beaches of western Phuket Island, Thailand. Bulletin of Marine Science 60(2): 240-251.
Eibye-Jacobsen D, Soares AG. 2000. New records of Scolelepis (Polychaeta: Spionidae) from the sandy beaches of Madagascar, with the description of a new species. Bulletin of Marine Science 67(1): 571-586.

Fauvel P. 1902. Annélides Polychètes de la Casamance rapportées par M. Aug. Chevalier. Bulletin de la Société Linnéenne de Normandie, Série 5(5): 59-105.

Fauvel P. 1927. Polychètes sédentaires. Addenda aux errantes, Arachiannélides, Myzostomaires. Faune de France Volume 16. Paul Lechevalier. Paris. 494 p.

Foster NM. 1971. Spionidae (Polychaeta) of the Gulf of Mexico and the Caribbean Sea. Studies on the Fauna of Curaçao and Other Caribbean Islands 37: 1-138.

Frolova EA, Lubina OS, Zimina OY, Dikaeva DR, Frolov AA, Akhmetchina OY, Garbul EA, Nekhaev IO. 2011. Benthic communities off the coast of the Arctic archipelagoes. Terrestrial and Marine Ecosystems. Paulsen Publishing House. Moscow - Saint-Petersburg: 181-210 (in Russian).

Gibbs PE. 1971. The polychaete fauna of the Solomon Islands. Bulletin of the British Museum (Natural History), Zoology 21(5): 101-211.

Golikov AN, Skarlato OA, Golikov AA, Ereskovsky AV, Menshutkina TV, Naumov AD, Novikov OK, Petryashov VV, Pogrebov VV, Sirenko BI, Frolova EA. 1989. The history of of formation and some features of the distribution of ecosystems in the Barents Sea Bay Yarnyshnaya. Problems Cenozoic paleo-ecology and paleo-geography of Arctic Ocean, Abstracts of the Third USSR Conference, Murmansk, Apatity: 13-14 (in Russian).

Gravier C. 1905. Sur les Annélides Polychètes de la Mer Rouge (Cirratuliens, Spionidiens, Ariciens). Bulletin du Muséum d'Histoire Naturelle, Paris, Série 1(11): 42-46.

Hartman O. 1954. New species of polychaetous worms from the Marianas and Gilbert Islands. Journal of the Washington Academy of Sciences 44(7): 228-232.

Hartman O. 1961. Polychaetous annelids from California. Allan Hancock Pacific Expeditions 25: 1-226.

Hartmann-Schröder G. 1959. Zur Ökologie der Polychaeten des Mangrove-Estero-Gebietes von El Salvador. Beiträge zur neotropischen Fauna 1(2): 69-183.

Hartmann-Schröder G. 1962. Die polychaeten des Eulitorals. In: Zur Kenntnis des Eulitorals der Chilenischen Pazifikküste und der Argentinischen Küste, südpatgoniens unter besonderer Berücksichtigung der Polychaeten und Ostracoden (G. Hartmann-Schöder \& Hartmann G. eds.). Mitteilungen aus dem Hamburgischen Zoologischen Museum und Institut 60: 57-167.

Hartmann-Schröder G. 1979. Die Polychaeten der tropischen Nordwestküste Australiens (zwischen Derby im Norden und Port Hedland im Süden). Teil 2. In: Hartmann-Schröder G. \& Hartmann G. Zur Kenntnis des Eulitorals der australischen Küsten unter besonder Berücksichtigung der Polychaeten und Ostracoden. Mitteilungen aus dem Hamburgischen zoologischen Museum und Institut 76: 77-218.

Hartmann-Schröder G. 1980. Die Polychaeten der tropischen Nordwestküste Australiens (zwischen Port Samson im Norden und Exmouth im Süden) In: Hartmann-Schroeder G. \& Hartmann G. Zur Kenntnis des Eulitorals der australischen Küsten unter besonder Berücksichtigung der Polychaeten und Ostracoden. Mitteilungen aus dem Hamburgischen zoologis- 
chen Museum und Institut 77: 41-110.

Hartmann-Schröder G. 1981. Zur Kenntnis des Eulitorals der australischen Kusten unter besonderer Berucksichtigung der Polychaeten und Ostracoden. Teil 6. Die Polychaeten der tropisch-subtropischen Westkuste Australiens (zwischen Exmouth im Norden und Cervantes im Suden). Mitteilungen aus dem Hamburgischen zoologischen Museum und Institut 78: 19-96.

Hartmann-Schröder G. 1984. Die Polychaeten der antiborealen Südküste Australiens (zwischen Albany im Westen und Ceduna im Osten). Teil 10. In: Hartmann-Schröder G. \& Hartmann G. Zur Kenntnis des Eulitorals der australischen Küsten unter besonderer Berücksichtigung der Polychaeten und Ostracoden. Mitteilungen aus dem Hamburgischen zoologischen Museum und Institut 81: 7-62.

Hartmann-Schröder G. 1991. Beitrag zur Polychaetenfauna der Bahia Quillaipe (Süd-Chile). Helgoländer wissenschaftliche Meeresuntersuchungen 45: 39-58.

Hutchings PA, Rainer S. 1979. The polychaete fauna of Careel Bay, Pittwater, New South Wales, Australia. Journal of Natural History 13: 745-796.

Hutchings PA, Turvey SP. 1984. The Spionidae of South Australia (Annelida: Polychaeta). Transactions of the Royal Society of South Australia 108(1): 1-20.

Hutchings PA, Frouin P, Hily C. 1998. Two new species of Spionidae (Polychaeta) Tahiti, French Polynesia. Proceedings of the Biological Society of Washington 111(4): 799-806.

Imajima M. 1959. A description of a new species of the Spionidae (Polychaeta), Nerinides yamaguchii n. sp., with notes on its development. Journal of Hokkaido Gakugei University 10(1): $155-165$.

Imajima M. 1992. Spionidae (Annelida, Polychaeta) from Japan, 8. The genus Scolelepis. Bulletin of the National Science Museum [Tokyo, Japan] 18: 1-34.

Jones ML. 1962. On some polychaetous annelids from Jamaica, The West Indies. Bulletin of the American Museum of Natural History 124 (5): 173-212.

Lyubina OS, Frolova EA, Dikaeva DR. 2012a. Current zoobenthos monitoring at the Kola Transect in the Barents Sea. A workshop celebrating two decades of cooperation between Murmansk Marine Biological Institute and Alfred Wegener Institute for Polar and Marine Research. Berichte zur Polar und Meeresforschung. N 640: 177-189.

Lyubina OS, Zimina OL, Frolova EA, Frolov AA, Nekhaev IO, Dikaeva DR. 2012b. Peculiarities of zoobenthos distribution in the coastal zone of the Kola Peninsula. Bulletin of Murmansk State Technical University 15(4): 776-785 (in Russian).

Maciolek NJ. 1987. New species and records of Scolelepis (Polychaeta: Spionidae) from the east coast of North America, with a review of the subgenera. Bulletin of the Biological Society of Washington 7: 16-40.

Matishov GG, Moiseev DV, Lubina OS, Zhichkin AP, Dzhenyuk SL, Makarevich PR, Frolova EA. 2011.Hydrobiological indicators of cyclic climate changes of the Western Arctic in XX-XXI centuries. "Vestnik Yuzhnogo Nauchnogo Tsentra" (Bulletin of the Southern Scientific Center of Russian Academy of Sciences) 7(2): 54-68 (in Russian).

Matishov GG, Moiseev D, Lyubina OS, Zhichkin A, Dzhenyuk S, Karamushko O, Frolova EA. 2012. Climate and cyclic hydrobiological changes of the Barents Sea from the twentieth to twenty- first centuries. Polar Biology 35(4): 625-631.

McIntosh WC. 1909. Notes from the Gatty Marine Laboratory, St. Andrews. No. 31. 1. On a young stage of Gadus luscus with bold transverse bars of pigment. 2. On the British Spionidae. 3. On the Spionidae dredged by H.M.S. «Porcupines in 1869 and 1870. Annals and Magazine of Natural History 3: 153-180.

Mesnil F. 1896. Études de morphologie externe chez les Annélides. I. Les Spionidiens des côtes de la Manche. Bulletin scientifique de la France et de la Belgique 29: 110-287.

Müller OF. 1806. Zoologia Danica seu Animalium Daniae et Norvegiae rariorum ac minus notorum, Descriptiones et Historia. Havniae. $160 \mathrm{p}$.

Okuda S. 1937. Spioniform polychaetes from Japan. Journal of the Faculty of Science, Hokkaido University, Ser. 6, Zoology 5(3): 217-254.

Orensanz JM, Gianuca NM. 1974. Contribuiçao ao conhecimento dos anelídos poliquetas do Rio Grande do sul, Brasil. I. lista sistematica preliminar e descriçao de très novas espécies. Comunicaçoes do Museo de Ciências da PUCRGS Porto Alegre 4: $1-37$.

Ozolinsh AV. 1990. [Two new species of Annelida, Polychaeta from Peter the Great Bay of the Japan Sea]. Zoologicheskii zhurnal 69(1): 131-135 (in Russian).

Pettibone MH. 1963. Revision of some genera of polychaete worms of the family Spionidae, including the description of a new species of Scolelepis. Proceedings of the Biological Society of Washington 76: 89-104.

Quatrefages A de. 1843. Déscription de quelques espèces nouvelles d'Annélides errantes recueillies sur côtes de la Manche. Magasin de Zoologie de Paris. Série 2(5): 1-16.

Reish DJ. 1959. New species of Spionidae (Annelida, Polychaeta) from southern California. Bulletin of the Southern California Academy of Sciences 58(1): 11-16.

Rioja E. 1918. Adiciones a la fauna de anelidos del Cantabrico. Revista de la Real Academia de Ciencias Exactas, Físicas y Naturales de Madrid 17: 54-79.

Rocha MB, Radashevsky V, Paiva PC. 2009. Espécies de Scolelepis (Polychaeta, Spionidae) de praias do Estado do Rio de Janeiro, Brasil. Biota Neotrop 9(4): 101-108. http://dx.doi.org/10.1590/ S1676-06032009000400012

Rocha MB, de Paiva PC. 2012. Scolelepis (Polychaeta: Spionidae) from the Brazilian coastwith a diagnosis of the genus. Zoologia 29 (4): 385-393. http://dx.doi.org/10.1590/S198446702012000400011

Rossi MM. 1982. A new species of Scolelepis (Polychaeta: Spionidae) from California sandy beaches. Bulletin of the Southern California Academy of Sciences 81(2): 97-100.

Rozbaczylo N, Castilla JC. 1988. A new species of polychaete, Scolelepis anakenae (Polychaeta:Spionidae) from Easter Island, South Pacific Ocean, with ecological comments. Proceedings of the Biological Society of Washington 101(4): 767-772.

Rzhavsky AV, Deart YV, Britayev TA. 2011. New records of arctic molluses and polychaetes: range expansion or poorly studied fauna? Proceedings of the International Scientific Conference "Global climatic processes and their effects on ecosystems of Arctic and Subarctic regions" (Murmansk, 9-11 November 2011), Apatity: 164-166 (in Russian).

Santos AS dos, Araujo Costaa D de, Christofersen ML. 2009. First record of Scolelepis (Scolelepis) lighti along the Brazilian 
coast. Marine Biodiversity Records 2: 1-5. http://dx.doi. org $/ 10.1017 /$ S1755267208000183

Sikorski AV. 1994. New arctic species of Scolelepis (PolychaetaSpionidae). In: Dauvin J-C, Laubier L and Reish DJ (eds). Actes de la 4ème Conférence internationale des Polychètes. Mémoires du Muséum National d'Histoire Naturelle 162: 279-286.

Sikorski AV. 2001. Spionidae of the Arctic Ocean. In: Jirkov IA. Polychaeta of the Arctic. Janus-K. Moskva: 273-332 (in Russian).

Silva PHDH. 1961. Contributions to the Knowledge of the Polychaete fauna of Ceylon. Part I. Five new species, two new varieties and several new records principally from the southern coast. Spolia Zeylanica 29(2): 164-194.

Southern R. 1914. Archiannelida and Polychaeta. Proc. Royal Ir. Acad. Dublin 31(47): 1-160.

Treadwell AL. 1914. Polychaetous annelids of the Pacific coast in the collection of the Zoological Museum of the University of California. University of California publications in zoology 13: $175-234$.

Treadwell AL. 1939. New polychaetous annelids from New England, Texas, and Puerto Rico. American Museum Novitates 1023: 1-7.

Treadwell AL. 1928. Polychaetous annelids from the Arcturus oceanographic expedition. Zoologica, New York 8: 449-485.

Tzetlin AB. 1985. Asetocalamyzas laonicola gen. et sp. n., a new ectoparasitic polychaete from the White Sea. Zoologicheskii zhurnal 64(2): 296-298 (in Russian).

Verrill AE. 1873. Report upon the invertebrate animals of Vineyard Sound and the adjacent waters, with an account of the physical characters of the region. Report of the United States Commission for Fisheries 1871-72: 295-778.

Vortsepneva E, Tzetlin A, Purschke G, Mugue N, HassCordes E, Zhadan A. 2008. The parasitic polychaete known as Asetocalamyzas laonicola (Calamyzidae) is in fact the dwarf male of the spionid Scolelepis laonicola (comb. nov.). Invertebrate Biology 127(4): 403-416. http://dx.doi.org/10.1111/ j.1744-7410.2008.00137.x

Williams JD. 2007. New records and description of four new species of spionids (Annelida: Polychaeta: Spionidae) from the Philippines: the genera Dispio, Malacoceros, Polydora, and Scolelepis, with notes on palp ciliation patterns of the genus Scolelepis. Zootaxa 1459: 1-35.

Wu BL, Chen M. 1964. A new species of polychaete worm of the Family Spionidae from Chushan Archipelago, East China Sea. Acta Zootaxonomica Sinica 1(1): 195-198.

Zhou J, Ji W, Li X. 2009. A new species of Scolelepis (Polychaeta: Spionidae) from sandy beaches in China, with a review of Chinese Scolelepis species. Zootaxa 2236: 37-49.

Zhou J. 2014. A new species of Scolelepis (Polychaeta: Spionidae) from Chinese seas. Raffles Bulletin of Zoology 62: 490-495.

Editorial responsibility: Torkild Bakken.

This article is open-access and distributed under the terms of the Creative Commons Attribution 4.0 International license. This permits all non-commercial use, distribution, and reproduction in any medium, provided the original work is properly cited.

(http://creativecommons.org/licenses/by/4.0/). 